abbreviations should be as uniform as is possible. This meeting of the American Chemical Society provided a welcome opportunity for those responsible on both sides of the Atlantic to meet and discuss this important matter. Semantics give us no decision between 'sulphur' and 'sulfur' or 'aluminium' and 'aluminum', but the two countries have found it possible to adopt the same symbols and identical logical methods for the necessary chemical shorthand.

As the oldest national ehemical society, the president of that of Great Britain was asked to convey the congratulations of the chemical societies invited to this meeting to our hosts; and Arthur B. Lamb, professor emeritus of Harvard, past editor of the Journal of the American Chemical' Society, was made an honorary life member of the Chemical Society in Great Britain.

In the proceedings of the International Congress, the world-wide ramifications of chemistry were most clearly revealed by the fact that the four official public lectures were given respectively by Prof. V. Deulofeu of Buenos Aires, Prof. K. U. LinderströmLang of Copenhagen, Dr. E. W. R. Steacie of Ottawa, Canada, and Prof. A. R. Todd of Cambridge in England, while the various committees and commissions of the Union and sections of the Congress were naturally international in character.

In Washington, the Union members were looked after by Dr. E. U. Condon, of the Bureau of Standards, and Dr. D. W. Bronk, of the National Academy of Science. The most important international action completed by the Union consisted in the re-admission of Japan and the admission of Western Germany and New Zealand to the Union. This meeting of the Union terminated the period under the presidency of Prof. H. R. Kruyt. Chemists who have the world interests of chemistry at heart are deeply indebted to one whose wisdom and skill have steered the Union through the difficult post-war period to a position in which it finds itself a living entity and has a real purpose in the complex times in which we live. Prof. Arne Tiselius was unanimously elected as successor, and the next meeting of the Union will be held in Stockholm in 1953. While the sectional meetings, of which there were so many, were managed with the skill born of long practice by the American Chemical Society, it proved too much for the Union, which found that having a congress of pure and applied chemistry on its hands was no joke. Delegates to the Union who thought they had sufficient work to do in the Union itself found that they had, in addition, to participate in many Congress activities. This, indeed, may be the last of the Congresses devoted to all phases of chemical activity. In Stockholm the Congress activities will be restricted to physical ehemistry and one or two special topies.

All visitors to the United States are always impressed by the kindness and hospitality of their hosts. Those who attended these conventions will never forget the attentions showered upon them by American individuals, civic authorities, societies and industrial organizations for fourteen memorable days. ERIC K. RIDEAT

\section{TWELTH INTERNATIONAL CONGRESS OF PURE AND APPLIED CHEMISTRY}

$\mathrm{T}$

HE Twelfth International Congress of Pure and Applied Chemistry was held in New York during September 9-13, immediately following the Diamond Jubilee celebrations of the American Chemical
Society. Chemists attending the Congress came from forty-two countries and, of more than nine hundred papers presented, about one-third were by chemists from countries outside the United States. Through the help of the Economic Co-operation Administration and also the Ford Foundation, a number of young chemists from foreign countries were able to attend the Congress and, after its conclusion, were taken on tours of the principal industrial centres of the United States. The Congress was divided into sixteen general sections, but, due to the large number of papers presented, some of these had to be subdivided further. In addition, a general lecture was given each day by a leading chemist (two from Europe, one from North and one from South America) to a combined meeting of all sections.

The first of the general lectures was given by Dr. E. W. R. Steacie, Division of Chemistry, National Research Council of Canada, and was entitled "The Decomposition of Organic Compounds". Taking as examples the thermal decomposition of ethane and the reaction of a methyl radical with an aliphatic hydrocarbon, he reviewed the different approaches and trends over the past few years in the field of gasphase reaction kinetics. He stressed that, though the original postulates and calculations about freeradical mechanisms have been useful in directing the investigations to date, much more experimental data are needed on a variety of simple reactions. The theoretical. approach now involves too many assumptions and approximations, and can only be further advanced when reliable experimental data have been amassed.

Prof. K. U. Linderström-Lang, of the Carlsberg Laboratories, Copenhagen, discussed, in his lecture "Structure and Enzymatic Breakdown of Proteins", the chemistry involved in the conversion of ovalbumin to plakalbumin. $\mathrm{He}$ presented evidence showing that when the protein ovalbumin is attacked by a bacterial proteolytic enzyme, the formation of plakalbumin II may correspond to the loss of a hexapeptide unit from the ovalbumin molecule. A reaction also occurs in which plakalbumin $\mathrm{I}$ is first formed, corresponding to the removal of a dipeptide (alanyl-alanine) from the original molecule, and then a tetrapeptide is split off more slowly to yield plakalbumin II. It was pointed out that although this comparatively small change in composition, namely, the removal of a peptide of low molecular weight, produces a remarkable change in the crystal form and solubility of the protein, dilatometric studies now reveal that there are other more profound changes in the molecule.

In the third lecture of the series, Prof. A. R. I'odd, University of Cambridge, discussed "The Chemistry of the Nucleotides". Keviewing recent work in this field, particularly that of the Cambridge group, Prof. Todd considered the approaches to nucleotide chemistry in relation to nucleic acid structure. Three chemical problems are involved : the structure and synthesis of nucleosides, the phosphorylation of these to give nucleotides, and the method of linkage of dissimilar bodies through the phosphoric acid group. In discussing these, the proof of the $\beta$. glycosidic linkage in the nucleosides was described, followed by an account of the use of dibenzyl chlorophosphonate as a mild phosphorylating agent. The uncertainty of the location of the phosphate group on either the 2- or 3-position of ribose in the nucleotides was explained by the possible cyclization 
of the phosphate group across these positions. This would also account for the alkali-instability of ribonucleic acid and for the isolation of isomeric adenylic acids by Carter and Cohn. In the light of the known chemical properties of the nucleotides, particularly their behaviour to acid and alkali, possible structures of ribo- and deoxyribo-nucleic acids were considered.

In the final lecture of the Congress, Prof. V. Deulofeu, National University of Buenos Aires, gave a short talk on "The Chemistry of some South American Plant Products". This dealt with the chemistry of the alkaloids and flavonols found in various plants and bushes in that region. The structure of $\gamma$-fagaradine and the other alkaloids from the plant Fagara coco was discussed by considering their relation to dictamine. The theoretical basis for their various reactions was considered, and the synthesis of analogues of $\alpha$-fagarine with comparable pharmacological activity was described. The three Argentine species of Erythrina examined contain two main alkaloid fractions, one group being the free bases (for example, erythramine, erythratine), while the others are glycosidically bound and only liberated in extractable form by acid hydrolysis (for example, erysotrine, erysovine). The structure and inter-relation of these compounds and their relation to the parent base erythradine were discussed.

Several of the larger sections of the Congress organized their programmes to include symposia on particular aspects of current interest. Thus the Medicinal Chemistry Section, for example, held symposia on antibiotics, tuberculosis and cancer. In these the stress fell mainly on the chemotherapeutic approach, several papers being presented on the new antibiotic 'viomycin', derived from Actinomyces vinaceus, and on the use of compounds of the thiosemicarbazone group against tuberculosis and of the derivatives of ethyleneimine against cancer. The Biological Chemistry Section held a two-day symposium on proteins and amino-acids, and also symposia on nucleic acids, enzymes and microbiological chemistry. The sections entitled Plant Cell-wall Constituents, Air and Stream Pollution, Pesticides, etc., held symposia on specific aspects in those fields. The Physical and Inorganic Chemistry Section and the Organic Chemistry Section arranged very large general programmes covering many aspects.

The field of chemistry has now become so vast that for future international meetings it seems it will be necessary to subdivide the Congress into independent units. Accordingly, the next International Congress of Chemistry, to be held at Stockholm in 1953 , in conjunction with a meeting of the International Union of Pure and Applied Chemistry, will be restricted solely to the Physical Chemistry Section.

D. H.AMER

\section{OBITUARIES \\ Mr. James Baddiley}

Mr. JAmes BADDILEY, who died in hospital on September 26, was one of the outstanding leaders in the renaissance of the dyestuffs industry in Great Britain. He was born in Yorkshire on July 15, 1885, and educated at Bradford Grammar School, whence he went to the University of Leeds and graduated with first-class honours in 1907. He then worked for two years with Prof. A. G. Green in the Clothworkers' Research Laboratory, and during this period published, with Green, in the Transactions of the Chemical Society, a paper in a series on colouring matters of the stilbene group, dealing with the action of caustic alkali on derivatives of $p$-nitrotoluene. In 1909 he joined Levinstein's, Ltd., at Blackley as research chemist, and in the next five years he worked chiefly on azo dyestuffs and intermediates, work which issued in twelve British patents with Dr. $\mathrm{H}$. Levinstein as co-inventor.

By the outbreak of war in 1914, Mr. Baddiley had already established his reputation as a research chemist, and he quickly became the head of the Technical Research Department at Blackley, of which he retained charge when the British Dyestuffs Corporation was formed. In 1925, Prof. A. G. Green having meanwhile resigned his post as director of research, Baddiley became manager of the Research: Department. In 1930, the British Dyestuffs Corporation having become part of Imperial Chemical Industries, Ltd., Mr. Baddiley became a delegate director, and joint technical manager of the Dyestuffs Group, remaining director in charge of research until his retirement in 1947.

Although only one scientific paper stands in his name, he was cited as co-inventor on some sixty British patent specifications. When the Board of Trade Dyestuffs Development Committee issued its first report in August 1920, it referred to five outstanding developments in dyestuffs chemistry, three of which were British discoveries, and with two of these Mr. Baddiley was associated. One was his discovery in 1922, with the late Mr. A. Shepherdson, of the valuable dyeing properties of dispersions of unsulphonated amino derivatives of anthraquinone for acetate rayon; the other was his contribution to the use of dispersions of azo dyestuffs for the same purpose. Both discoveries considerably assisted the development of the use of cellulose acetate as a textile fibre. A further discovery, also listed by the Dyestuffs Development Committee in its report, with which Mr. Baddiley was associated, was that of a special range of azo dyes giving level shades on the 'irregular' viscose rayon which at that time was frequently encountered. Mr. Baddiley's services to the industry were recognized in February 1939 by the award to him of the Perkin Medal of the Society of Dyers and Colourists. This, the premier award in the field of dyes and their application and textile chemical technology, was awarded "in recognition of his national services for the renaissance of the British dyestuffs industry through many important investigations in the field of colouring matters conducted or directed by him".

Mr. Baddiley retained to the end his interest in and enthusiasm for dyestuffs technology and organic chemistry, remaining a keen student of the literature. Only his last illness prevented him from presenting a paper he had prepared for the Society of Dyers and Colourists' conference last September. Outside chemistry his chief interests were in his family and, in early life, walking in the Peak district, the Lake district, or his native county, of the fells and inns of which he had an extensive knowledge. He came of farming stock and had also a keen interest in agriculture.

On the research side at least, no one clse can have played a part in the renaissance of the British dyestuffs industry in any way comparable with that of Mr. Baddiley; but some who knew him may remem- 